\title{
The use of zoobenthos for the assessment of water quality in canals influenced by landfilling and agricultural activity
}

\author{
Sử dụng động vật đáy đánh giá chất lượng nước kênh ảnh hưởng do bãi chôn lấp rác và hoạt \\ động sản xuất nông nghiệp
}

NGUYEN, Thanh Giao

Department of Environmental Management, College of Environment and Natural Resources, Can Tho University. 3/2 Street, Ninh Kieu District, Can Tho City, Viet Nam

\begin{abstract}
The aquatic environment and zoobenthos are closely related in a water body. In recent years, the use of zoobenthos to evaluate water quality is getting more attention as this approach is less polluting and less costly. This study was conducted to assess the diversity of zoobenthos in the canals affected by leachate and agricultural activities. Five sediment samples were collected in two campaigns, one in April and one in October 2018. Water samples were also collected at the same time for zoobenthos to assess the water quality and serve as a reference for assessing the effectiveness of using zoobenthos as water quality indication. In total, 17 species of zoobenthos belonging to six families and four classes were identified, of which Limnodrilus hoffmeisteri and Tendipes species being present regularly at sampling sites through the surveys. The calculations of the Shannon-Wiener diversity index $\left(\mathrm{H}^{\prime}\right)$, rapid bioassessment protocol (RBP III), and associated average score per taxon (ASPT) indices based on species composition indicated that the water environment surrounding the landfill was moderately to severely polluted. However, the water quality index (WQI) calculated based on the physical and chemical properties shows that the level of water pollution in canals was less than that evaluated using zoobenthos. This can be explained by the fact that zoobenthos also affected the properties of sediments which depend on the water column. The findings in this study showed that the aquatic environment around the landfill is heavily contaminated as result of waste disposal and agricultural activities. The use of both zoobenthos combined with physical and chemical indicators could be useful in assessing the canals' water status.
\end{abstract}

Môi trường nước và động vật đáy có liên quan mật thiết với nhau trong một thủy vực. Trong những năm gần đây, việc sử dụng động vật đáy để đánh giá chất lượng môi trường nước mặt được quan tâm vì phương pháp này ít gây ô nhiếm môi trường và ít tốn kém chi phí. Nghiên cứu được tiến hành để đánh giá sự phân bố của động vật đáy trong hệ thống kênh rạch chịu tác động từ nước rỉ rác và các hoạt động sản xuất nông nghiệp. Năm mẫu động vật đáy được thu hai đợt, đợt 1 vào tháng 4 và đợt 2 vào tháng 10 năm 2018. Mẫu nước cũng được thu để đánh giá chất lượng nước và làm cơ sở đánh giá hiệu quả của việc sử dụng động vật đáy làm chỉ thị chất lượng môi trường nước. Kết quả nghiên cứu cho thấy thành phần động vật đáy phát hiện 17 loài thuộc 6 họ và 4 lớp, trong đó các loài Limnodrilus hoffmeisteri và loài Tendipes hiện diện thường xuyên ở tất cả các điểm thu mẫu qua hai đợt khảo sát. Dựa vào thành phần loài tính toán các chi số Shannon-Wiener (H'), chỉ số đánh giá nhanh sinh học (RBP III), và chi số tính điểm trung bình bình theo họ (ASPT) cho thấy môi trường ô nhiễm rất nặng trong khi đó chi số WQI được tính toán dựa vào các chi tiêu lý hóa cho thấy mức độ ô nhiễm nước ở kênh xung quanh bãi rác chỉ ở mức nhe hơn. Như vậy, việc sử dụng động vật đáy cho kết quả đánh giá chất lượng nước với mức độ ô nhiễm cao hơn. Điều này có thể giải thích là do động vật đáy chịu ảnh hưởng bởi đặc tính nền đáy và cột nước bên trên nền đáy. Kết quả nghiên cứu cho thấy môi trường nước xung quanh bãi rác bị ô nhiễm nặng do xả thải và hoạt động sản xuất nông nghiệp. Việc sử dung động vật đáy kết hợp với các chi tiêu lý, hóa có thể hữu ích hơn trong việc đánh giá hiện trạng nước kênh.

Keywords: agricultural activity, zoobenthos, sediment, landfill, pollution

\section{Introduction}

Solid waste generation is getting more attention for environmental management authorities in Vietnam due to rapid increase of population and social-economic development. Total amount of solid waste generated at national level in 2014 was 32,000 tons per day (Ministry of Natural
Resources and Environment, 2015). Yearly, the average increase of solid waste generating rate is approximate 12\% (Ministry of Natural Resources and Environment, 2015). The average rates of solid waste generation were at 0.75 and $0.61 \mathrm{~kg} /$ person/day in the whole nation and in the Vietnamese Mekong Delta, respectively (Ministry of Natural Resources and Environment, 2015). Dong Thang landfill is located in Co Do District, Can Tho City with the total area 
of 6 ha. The landfill is divided into three cells, four leachate collection ponds, and spare area of 0.9 ha. Two incinerators have been installed to incinerate wastes. The incinerators could burn 10 tons of wastes per day while leaving 170 tons in the landfill. The landfill is now not properly managed because solid wastes have not been classified and the buried wastes are not properly covered. In addition, leachate is not appropriately treated although it is daily generated. Thus, pollution in the surrounding areas of the landfill is unavoidable. Therefore, environmental monitoring is urgently needed. Water quality monitoring using physical, chemical and biological parameters are commonly applied in Vietnam. In addition, zoobenthos are also used to assess water pollution (Quynh, 2008; Lien et al., 2014) and ecological zoning (Dung et al., 2008) because of its sensitivity to changes in water quality due to natural and anthropogenic causes. Zoobenthos comprise insect larvae, annelids, mollusca, macrocrustaceans, and benthic microcrustacean. Zoobenthos play a vital role in water bodies since it is responsible for maintaining stable food webs, able to purify water, and used as indicators for the environmental quality (Hellawell, 1986). Zoobenthos exhibit characteristics such as long lifetime and tolerance to environmental pollution, which makes them important for indicating the quality of water and sediment (Hellawell, 1986; Khoa et al., 2007). This study was conducted to assess the status of surface water environment affected by landfilling and agricultural production. Sediment and water samples were collected for comparing the results of the physical and chemical analysis to the results of water indication of zoobenthos. The outcomes of this study could provide useful information on the current state of the environment influenced by leachate and agriculture so that authority and environmental managers could take appropriate measures for impact minimization.

\section{Materials and methods}

\subsection{Study site and sampling procedures}

Dong Thang landfill in Co Do district, Can Tho city, Viet Nam currently receives 180 tons of municipal and agricultural solid wastes from seven districts in Can Tho. At present, leachate from the landfill is collected in ponds without any treatment. Leachate could be discharged directly into the environment causing adverse effects on water, soil, and organisms. The landfill site is surrounded by rice fields and two canals as indicated in Figure 1 . These canals are suspected to receive some leachate from the landfill operation and discharge it into the bigger canal, whose water is used by the surrounding households for daily activities. For assessing the surface water quality in these canals, water and sediment samples were collected for physical-chemical and zoobenthos analysis (Table 1).

Table 1. Information on sampling sites

\begin{tabular}{|c|c|c|c|c|c|}
\hline \multirow{2}{*}{ No. } & \multirow{2}{*}{ Code } & \multicolumn{3}{|c|}{ Coordinates } & \multirow{2}{*}{ Description } \\
\hline & & Types of samples & Latitude & Longitude & \\
\hline 1 & $x_{1}$ & $\begin{array}{l}\text { - Water sample } \\
\text { - Zoobenthos }\end{array}$ & $10^{\circ} 5^{\prime} 12.15^{\prime \prime} \mathrm{N}$ & $105^{\circ} 27^{\prime} 47.39^{\prime \prime} \mathrm{E}$ & $\begin{array}{l}\text { A section of canal passes through the landfill. During the sur- } \\
\text { vey, it was noted that the untreated leachate was flowing into } \\
\text { the canal. At the time of sample collection the water was } \\
\text { poorly exchanged or static. }\end{array}$ \\
\hline 2 & $x 2$ & $\begin{array}{l}\text { - Water sample } \\
\text { - Zoobenthos }\end{array}$ & $10^{\circ} 5^{\prime} 11.81^{\prime \prime} \mathrm{N}$ & $105^{\circ} 27^{\prime} 52.71^{\prime \prime} \mathrm{E}$ & $\begin{array}{l}\text { X2 is on the same canal section with X1. At this site, the canal } \\
\text { was full of water hyacinths (leaving and dead plants), floating } \\
\text { solid waste, and the water was poorly exchanged. }\end{array}$ \\
\hline 3 & X3 & $\begin{array}{l}\text { - Water sample } \\
\text { - Zoobenthos }\end{array}$ & $10^{\circ} 5^{\prime} 9.79^{\prime \prime} \mathrm{N}$ & $105^{\circ} 28^{\prime} 0.76^{\prime \prime} \mathrm{E}$ & $\begin{array}{l}\text { The intersection of the two canals. This site was character- } \\
\text { ized by high water flow, good water exchange, and high } \\
\text { transport activities. }\end{array}$ \\
\hline 4 & $x 4$ & - Zoobenthos & $10^{\circ} 5^{\prime} 6.12^{\prime \prime} \mathrm{N}$ & $105^{\circ} 27^{\prime} 55.90^{\prime \prime} \mathrm{E}$ & $\begin{array}{l}\text { High water flow, good water exchange. At this location the } \\
\text { canal received water from rice fields and this paddy field also } \\
\text { receives leachate from the landfill. }\end{array}$ \\
\hline 5 & $\times 5$ & $\begin{array}{l}\text { - Water sample } \\
\text { - Zoobenthos }\end{array}$ & $10^{\circ} 5^{\prime} 0.44^{\prime \prime} \mathrm{N}$ & $105^{\circ} 27^{\prime} 48.09^{\prime \prime} \mathrm{E}$ & $\begin{array}{l}\text { Clear flow, good water exchange. There is a gate connecting } \\
\text { the leachate collection pond to the canal. }\end{array}$ \\
\hline
\end{tabular}




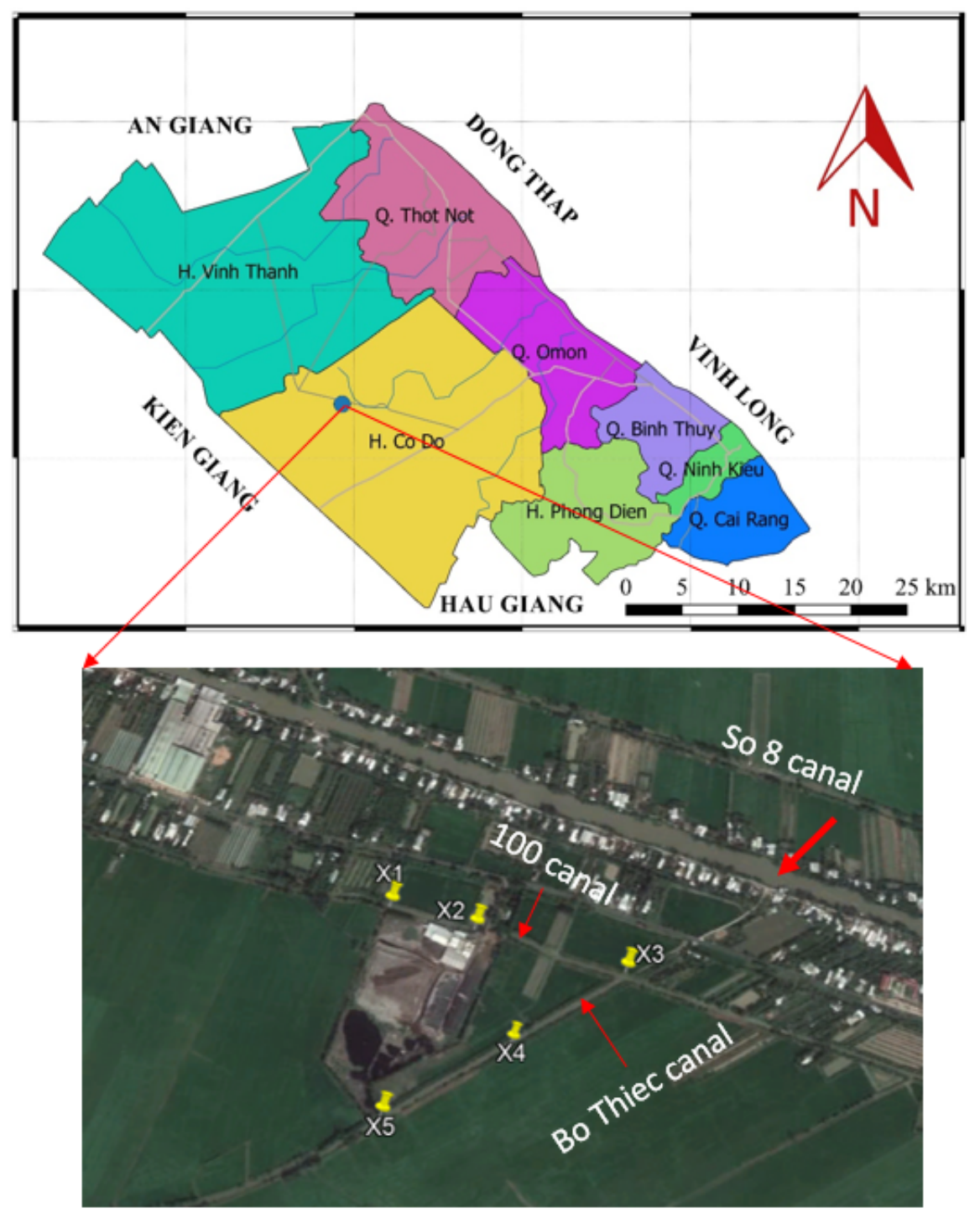

Figure 1. Locations of sampling sites (Google Earth, 2019)

\subsection{Zoobenthos}

Zoobenthos were collected using a Petersen gauge (Wijeyaratne and Kalaotuwave, 2017), with the open mouth area of $0.02 \mathrm{~m}^{2}$, in five locations (namely X1, X2, X3, X4 and $X 5)$ in the canals around the landfill as indicated in Figure 1. At each sampling point, zoobenthos were collected five times and mixed together. The collected samples were sieved through a mesh of $0.5 \mathrm{~mm}$ to remove mud and debris. The sieved samples were then stored in nylon bags and fixed in a solution of 8-10\% formaldehyde. In the laboratory, the collected benthic macroinverterbrates were fixed in 4\% formaldehyde solution (Nhu et al., 2012) until qualitative and quantitative analyses were carried out. For qualitative analysis, zoobenthos were observed using a microscope to determine the morphological, structural and classification characteristics following the taxonomy textbooks of Thanh et al. (1980) and Quynh et al. (2001). For quantitative analysis, zoobenthos were enumerated then the counted numbers were used for calculation of diversity indices as follows:
The Shannon - Wiener diversity index $\left(\mathrm{H}^{\prime}\right)$ was calculated using Equation 1 (Wilhm and Dorris, 1968):

$H^{\prime}=-\sum p_{i} \cdot \ln p_{i}$

(Equation 1)

where $p_{\mathrm{i}}=n_{\mathrm{i}} / N_{i} n_{\mathrm{i}}$ represents the numbers of ith individual; $N$ is the total amount of individuals in the samples.

The rapid bioassessment protocol (RBP III) was calculated using Equation 2 (Plafkin et al., 1989):

$F B /=\sum \frac{x_{i} \cdot t_{i}}{N}$

(Equation 2)

where $F B$ is the Family Biotic Index, $x_{i}$ represents the numbers of individuals of the ith family; $t_{i}$ is the tolerant value of ith family; $N$ is the total individuals of zoobenthos in the sample.

The associated average score per taxon (ASPT) BMWPVIETNAM was calculated using Equation 3 (Richard et al., 1997): 
$A S P T=\frac{\sum_{i=1}^{n} B M W P}{N}$

(Equation 3)

where $N$ is total families used for calculating tolerance point; BMWP is BMWPVET NAM.

\subsection{Water sampling and analysis}

Water samples were collected at four locations as shown in Figure 1. The samples were stored in plastic bottles with a volume of $2000 \mathrm{ml}$ and transported in an icebox to the Laboratory for Environmental Analysis, College of Environment and Natural Resources, Can Tho University, Vietnam. The $\mathrm{pH}$, electrical conductivity (EC, $\mu \mathrm{S} / \mathrm{cm})$, total suspended solids (TSS, mg/L), biochemical oxygen demand (BOD, $\mathrm{mg} / \mathrm{L})$, chemical oxidation demand (COD, $\mathrm{mg} / \mathrm{L})$, nutrients $\left(\mathrm{NH}_{4}{ }^{+}-\mathrm{N}, \mathrm{NO}_{3}{ }^{-}-\mathrm{N}, \mathrm{PO}_{4}{ }^{3-}-\mathrm{P}, \mathrm{mg} / \mathrm{L}\right)$ were analyzed according to the Standard Methods for the Examination of Water and Wastewater (APHA, 1998).

The Water Quality Index (WQI) was calculated based on Equation 4 (National Environmental Protection Agency, 2011):

$W Q I=\frac{W Q I_{p H}}{100}\left[\frac{1}{4} \sum_{a=1}^{4} W Q I_{a} \cdot W Q I_{b}\right]^{1 / 2}$

(Equation 4)

Where $W Q l_{a}$ is $W Q /$ calculated for $\mathrm{BOD}, \mathrm{COD}, \mathrm{NH}_{4}^{+}-\mathrm{N}_{1} \mathrm{PO}_{4}{ }^{3-}$ -P; WQ/b is WQI calculated for TSS; WQ/pH is WQI calculated for $\mathrm{pH}$.

\section{4 Cluster analyses}

Cluster Analysis (CA) was used to group the sampling positions according to the composition of zoobenthos, then presented in the form of a dendrogram. The clusters were analyzed using PRIMER software V5.2.9 (Clarke and Wawick, 1994) following the Ward method (Salah et al., 2012).

\section{Results and discussion}

\subsection{Assessment of water quality using physical and chemical parameters}

\subsubsection{Total suspended solids (TSS)}

TSS concentrations in the first sampling campaign (dry season) ranged between 12 and $33 \mathrm{mg} / \mathrm{L}$ while in the second campaign (rainy season) the TSS concentration was between 43-78.5 mg/L (Figure 2). The increase in TSS content during the rainy season could be due to the influence of run-off and turbulence. In the sampling campaign, TSS at X2 exceeded the National technical regulations for surface water quality (QCVN 08-MT: 2015/BTNMT, column A1: “Use for domestic water supply purposes (after application of normal treatment), conservation of aquatic plants and an- imals and other purposes"), while TSS at X3 and X4 exceeded the national standard, column A2: "Used for water supply purposes but must apply appropriate treatment technology or other uses". The TSS concentration at X1 was low during the first sampling campaign because the low flow velocity led to least water turbulence. In the second sampling campaign, the TSS concentration at X1 and X4 eXceeded the values corresponding to column A2 of the same national standard while the values measured at X2 and X3 surmounted the column B1: "Use for irrigation or other uses with similar water quality requirements".

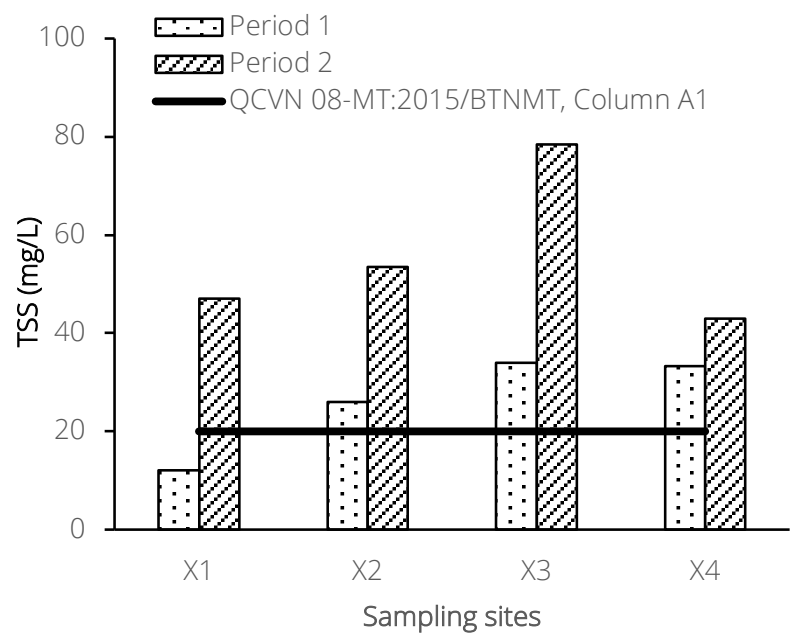

Figure 2. Variation of TSS concentration in the canals

\subsubsection{Chemical oxygen demand (COD)}

Chemical oxygen demand fluctuated slightly between the two surveys (Figure 3). At the sampling sites, COD ranged from 12 to $19.22 \mathrm{mg} / \mathrm{L}$, the lowest COD concentration in the two periods were recorded at X 4 while the highest COD concentration was recorded in the first sampling campaign at X2 (19.22 mg/L).

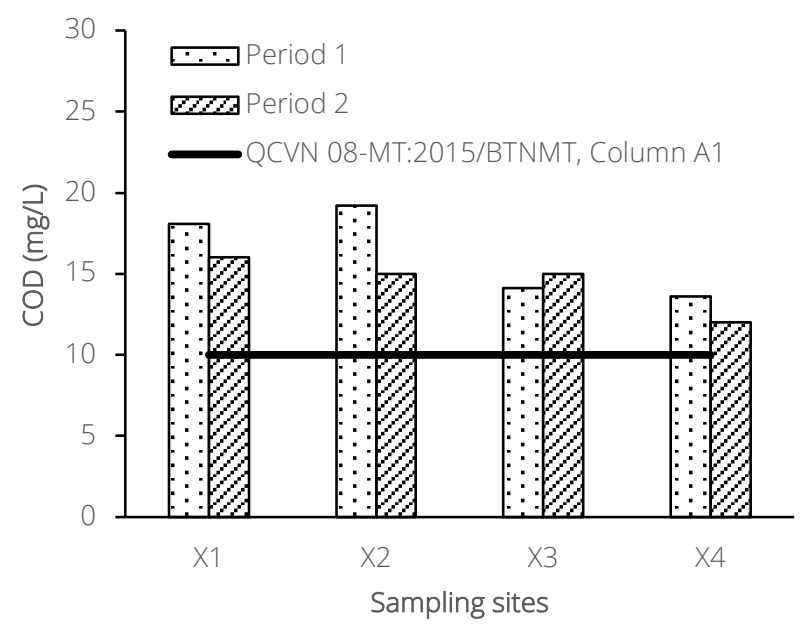

Figure 3. Variation of COD concentration in the canals

The concentrations at the sampling sites $X 1$ and $X 2$ were high because the water at these sites received leachate from the landfill and the water was poorly exchanged. The COD level was slightly higher in the first sampling campaign 
(except for $\mathrm{X} 3$ ) because this is the dry season resulting in low water level in canals which could lead to concentration of contaminants. It can be observed that the COD concentration at all sampling locations in the canals exceeded the permissible limit of the National technical regulations for surface water quality (QCVN 08-MT: 2015/BTNMT, Column A1).

\subsubsection{Biological oxygen demand (BOD)}

The values of BOD showed large fluctuation over the two sampling periods in which BOD of the second sampling round was 2-4 times higher than that of the first sampling (Figure 4). This result was consistent with the TSS concentrations which were also higher in the second sampling round. It could be implied that most suspended solids were biodegradable organic matters. All BOD values in the first sampling round at all surveyed sites were in line with the permitted standards (QCVN 08-MT: 2015/BTNMT, column A1) while those of the second sampling period readily exceeded the allowable limit (column A2). The findings clearly showed that organic matters from landfill and surrounding areas were higher dispersed into canals in the rainy season.

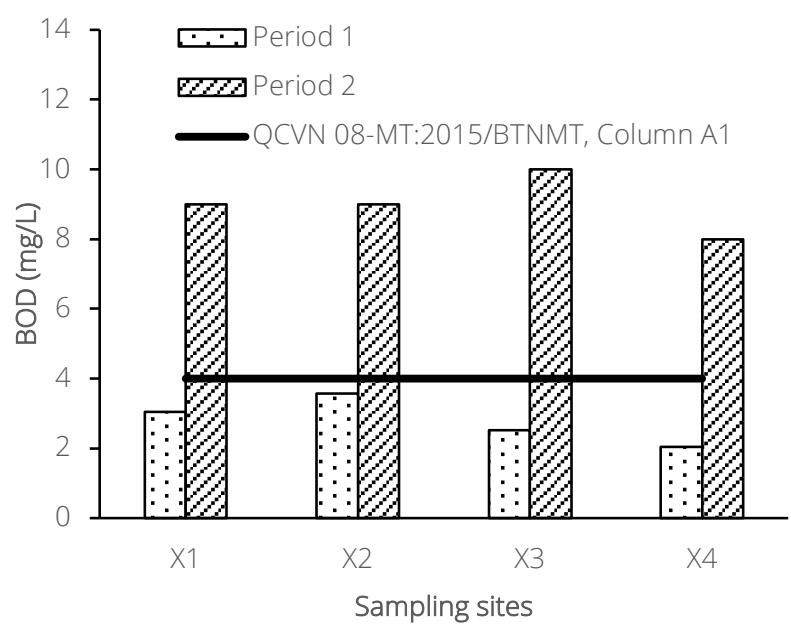

Figure 4. Variation of BOD concentration in the canals

\subsubsection{Ammonium $\left(\mathrm{NH}_{4}^{+}-\mathrm{N}\right)$}

The $\mathrm{NH}_{4}{ }^{+}-\mathrm{N}$ concentration in the first and second sampling campaigns ranged from 0.44-1.72 $\mathrm{mg} / \mathrm{L}$ and 0.19-0.94 $\mathrm{mg} / \mathrm{L}$, respectively (Figure 5). In contrast to the increasing tendency of BOD concentration, the concentrations of $\mathrm{NH}_{4}{ }^{+}-\mathrm{N}$ in the first sampling round were higher than those in the second sampling period (except for X4). The $\mathrm{NH}_{4}{ }^{+} \mathrm{N}$ concentration at $X 1$ and $X 2$ tends to be higher than $X 3$ and $X 4$ because the distance from the landfill to $X 1$ and $X 2$ is closer than from the landfill to $X_{3}$ and $X 4$. The highest $\mathrm{NH}_{4}{ }^{+}-\mathrm{N}$ concentration was found at $\mathrm{X} 1(1.72 \mathrm{mg} / \mathrm{L})$ because this location frequently receives the leachate leaking from the landfill. $\mathrm{NH}_{4}^{+}-\mathrm{N}$ in two surveys exceeded the national regulations for surface water quality (except for $\mathrm{X} 3$ at the second sampling period). It was noted that $\mathrm{NH}_{4}{ }^{+}-\mathrm{N}$ at $\mathrm{X} 1$, X2 exceeded the permissible level of column A2. It was clearly showed that the canals were polluted by $\mathrm{NH}_{4}{ }^{+}-\mathrm{N}$ that could lead to oxygen-deficiency and toxicity for aquatic life.

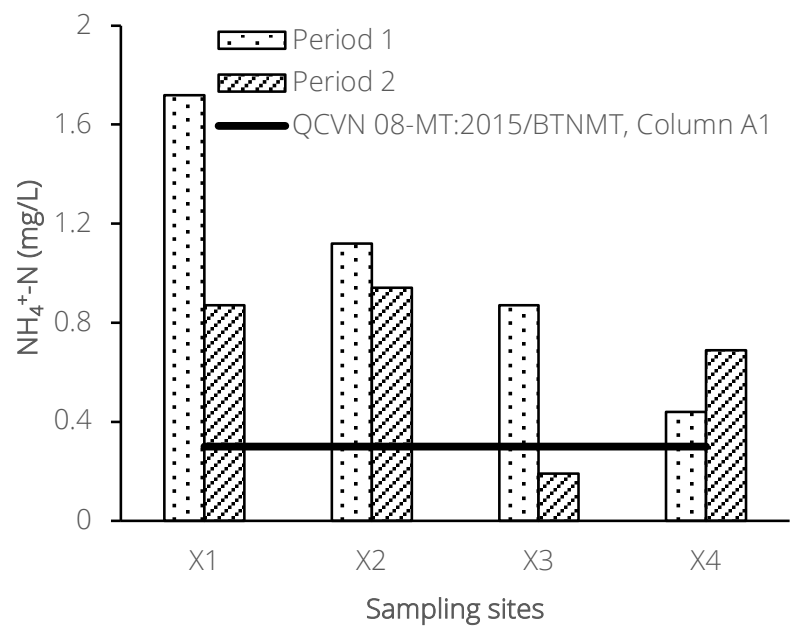

Figure 5. Variation of $\mathrm{NH}_{4}{ }^{+}-\mathrm{N}$ concentration in the canals

\subsubsection{Nitrate $\left(\mathrm{NO}_{3}{ }^{-}-\mathrm{N}\right)$}

The levels of $\mathrm{NO}_{3}{ }^{-}-\mathrm{N}$ in the two surveys ranged from 0.08 to $0.51 \mathrm{mg} / \mathrm{L}$ and concentration of $\mathrm{NO}_{3}{ }^{-} \mathrm{N}$ in the first sampling round were higher than those of the second round (Figure 6). Unlike $\mathrm{NH}_{4}{ }^{+}-\mathrm{N}$, the concentration of $\mathrm{NO}_{3}{ }^{-} \mathrm{N}$ tends to increase from $X 1$ to $X 4$ may be due to the more presence of dissolved oxygen and nitrogen-converting microbes. In general, $\mathrm{NO}_{3}{ }^{-} \mathrm{N}$ at all survey sites in two sampling rounds were not over the permitted limit of QCVN 08MT: 2015/BTNMT, Column A1.

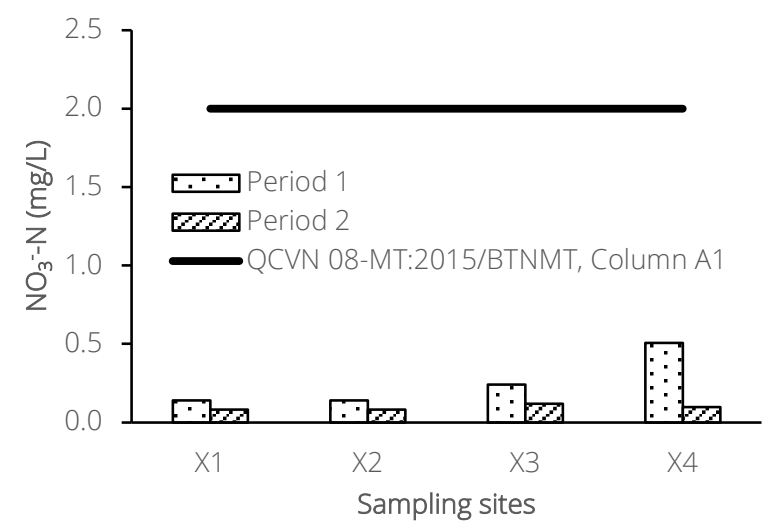

Figure 6. Variation of $\mathrm{NO}_{3}^{-}-\mathrm{N}$ concentration in the canals

\subsubsection{Orthophosphate $\left(\mathrm{PO}_{4}^{3-}-\mathrm{P}\right)$}

The $\mathrm{PO}_{4}{ }^{3-}-\mathrm{P}$ concentrations at the sampling sites in the dry season was higher than those in the rainy season, except for X3 site (Figure 7). At the location X3, in addition to orthophosphate, the concentrations of TSS, BOD and COD of the second sample round were all higher than those in the first sampling round. Orthophosphate was not detected at $x 4$ during the rainy season that could be due to the dilution effect. Generally, $\mathrm{PO}_{4}{ }^{3-}-\mathrm{P}$ at all study sites remains within the national standards (QCVN 08-MT: 2015/BTNMT, column A1). However, orthophosphate at X1 and X2 in the dry season approaches the set standard. 


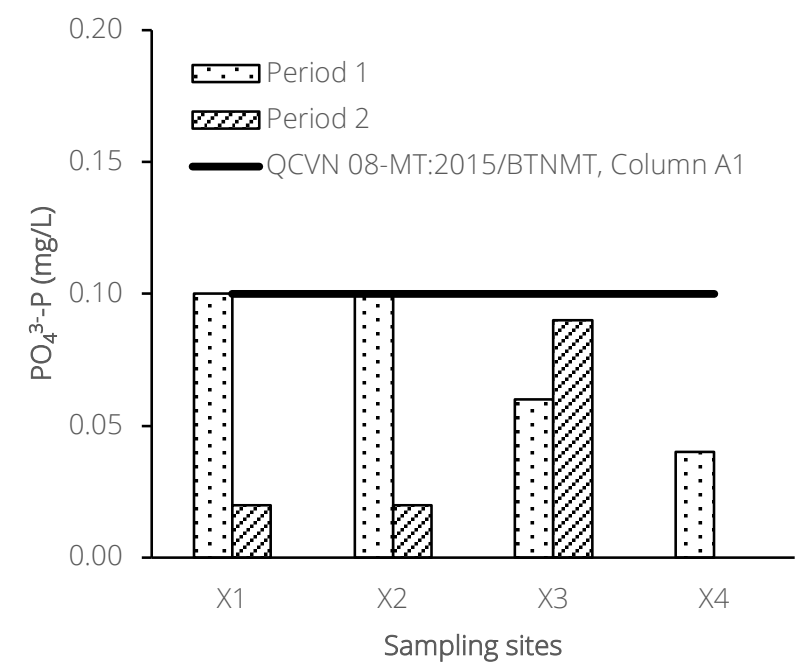

Figure 7. Variation of $\mathrm{PO}_{4}{ }^{3-}-\mathrm{P}$ concentration in the canals

\subsubsection{Water quality index (WQI)}

The WQI is ranging from 0 to 100 dividing water quality into five levels (National Environmental Protection Agency,
2011). Level 1 or Excellent $(100>W Q I>91)$ is excellent water quality that could be directly used for purposes of water supply. Level 2 or Good ( $90>$ WQI > 76) is also used for water supply for domestic uses but suitable treatment measures are required. Level 3 or Medium is for irrigation and other similar purposes $(75>\mathrm{WQI}>51)$. Level 4 or Bad $(50>W Q I>26)$ is the water suitable for transport and equivalent purposes while Level 5 or Very bad (25 > WQI > 0 ) is considered to be heavily polluted water that proper treatment measures are urgently needed.

The water quality index was in the range of 63-72 for the dry season and 53-67 for the rainy season (Figure 8). This result was consistent with the previous discussion that several water parameters (TSS, BOD, $\mathrm{COD}$, and $\mathrm{PO}_{4}{ }^{3-}-\mathrm{P}$ ) in the rainy season were higher than those of the rainy season. Based on WQI values, it could be concluded that the surface water in the canals has been contaminated, not meeting the requirements of irrigation (Level 3-Medium). This means that the use of this water source may affect the agricultural productivity.

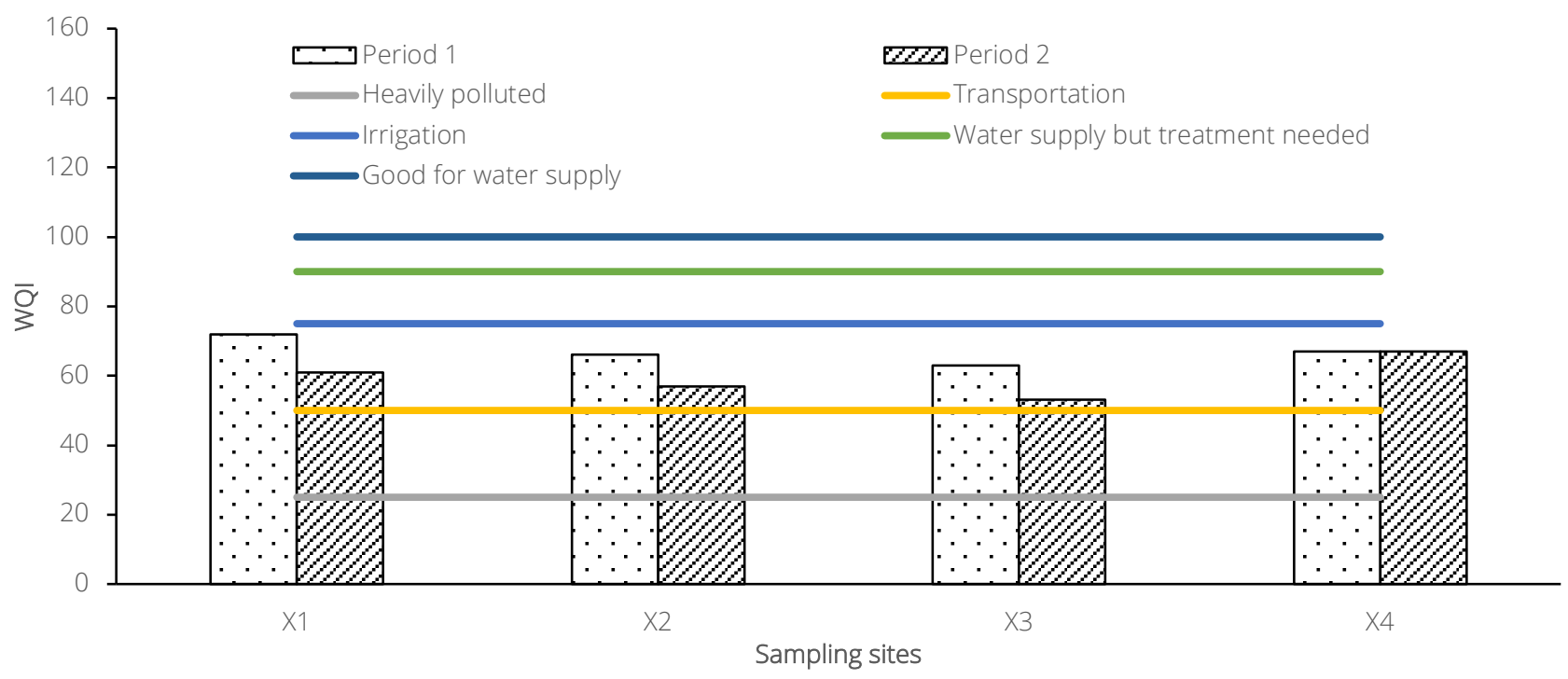

Figure 8. WQI in the canals

\subsection{Assessment of water quality using zoobenthos}

\subsubsection{Description of the zoobenthos in the sampling period}

The variation in the species composition of zoobenthos by locations and sampling periods was presented in Table 2. It can be seen that during the two surveys, D1 had limited numbers of species occurrence including only Limnodrilus hoffmeisteri and Tendipes. The least diversity at D1 was due to the impact of leachate leaching from the landfill. At D2, four species were found in the first sampling period in which Limnodrilus hoffmeisteri was the dominant species, whereas in the second sampling period only Tendipes was found at D2. The reduction of numbers of species could be linked to the decrease of WQI values at D1 and D2 during the second sampling campaign (Figure 8). At D3, 11 species belonging to five families and four classes were found during the first sampling times, of which the species including dominant species of Limnodrilus hoffmeisteri (27 individuals) and Tubifex sp. (4 individuals) (Table 2). At the second round of the sampling at D3, only three species of Tendipes, Limnodrilus hoffmeisteri, and Cipangopaludina lecythoides were found, but the numbers of individuals of each species were only 1, 2 and 1, respectively, which were significantly lower than those of the first sampling times. This decrease in species composition well corresponded to a decrease in WQI from 63 in the first sampling period to 53 in the second one (Figure 8). At D4 in the first sampling period, there was occurrence of three species including Limnodrilus hoffmeisteri, Tubifex sp, and Metriocnemus Knabi coq belonged to two families and two classes. At this sampling site, Lim- 
nodrilus hoffmeisteri (13 individuals) and Tubifex sp. (4 individuals). In the second sample collection, six species belonging to four families and three classes of zoobenthos were found. Of the six species presence, Limnodrilus hoffmeisteri, Tubifex sp. and Tendipes dominated with the numbers of individuals of 33, 6, and 5, respectively (Table 2). The superiority of Limnodrilus hoffmeisteri, Tubifex sp indicates that the water environment is organically polluted.

At D5, seven species, four classes, and four families were identified. Among the seven species, Limnodrilus hoffmeisteri, Sinotaia basicarinata, and Tubifex sp. were predominant. The second sampling campaign at D5 was character-

\section{Table 2. Diversity of zoobenthos over two sampling periods}

Class Family Species

ized by less diverse zoobenthos. There were only four species found belonging to three families and three classes. Similar to the first sampling, Limnodrilus hoffmeisteri and Tubifex sp. were the dominant species. Based on the zoobenthos indication, the aquatic environment at the study area was organically polluted. This finding was in line with the use of WQI (WQI for both the first and the second sampling rounds was 67) for water quality classification (Figure 8). The superiority of Tubificidae family at all sampling sites on the canals around the landfill indicated that the water environment was heavily organically polluted. The causes could be from the landfill operation and possibly partly from agricultural activity (Nhan et al., 2016).

\begin{tabular}{|c|c|c|c|c|}
\hline & & & \\
\hline & & & Period 1 & Period 2 \\
\hline \multicolumn{5}{|l|}{$\mathrm{X} 1$} \\
\hline Insecta & Chironomidae & Tendipes & 0 & 5 \\
\hline Oligochaeta & Tubificidae & Limnodrilus hoffmeisteri & 14 & 0 \\
\hline \multicolumn{5}{|l|}{$X 2$} \\
\hline Insecta & Chironomidae & Tendipes & 0 & 1 \\
\hline Gastropoda & Viviparidae & Filopaludina sumatrensis & 7 & 0 \\
\hline Gastropoda & Thiaridae & Melanoides tuberculatus & 1 & 0 \\
\hline Oligochaeta & Tubificidae & Limnodrilus hoffmeisteri & 56 & 0 \\
\hline Gastropoda & Viviparidae & Sinotaia basicarinata & 2 & 0 \\
\hline \multicolumn{5}{|l|}{$x 3$} \\
\hline Insecta & Chironomidae & Tendipes & 1 & 1 \\
\hline Insecta & Chironomidae & Metriocnemus edwardsi Jones & 1 & 0 \\
\hline Polychaeta & Nereididae & Namalycastis longicirris & 2 & 0 \\
\hline Oligochaeta & Tubificidae & Limnodrilus hoffmeisteri & 27 & 2 \\
\hline Oligochaeta & Tubificidae & Tubifex sp & 4 & 0 \\
\hline Oligochaeta & Tubificidae & Brachyura sowerbyi & 1 & 0 \\
\hline Gastropoda & Viviparidae & Filopaludina sumatrensis & 1 & 0 \\
\hline Gastropoda & Viviparidae & Angulyagra polyzonata & 2 & 0 \\
\hline Gastropoda & Viviparidae & Filopaludina javanica & 1 & 0 \\
\hline Gastropoda & Viviparidae & Angulyagra boettgeri & 1 & 0 \\
\hline Gastropoda & Viviparidae & Cipangopaludina lecythoides & 0 & 1 \\
\hline \multicolumn{5}{|l|}{ X4 } \\
\hline Insecta & Chironomidae & Metriocnemus Knabi coq & 1 & 0 \\
\hline Insecta & Chironomidae & Tendipes & 0 & 5 \\
\hline Oligochaeta & Tubificidae & Limnodrilus hoffmeisteri & 13 & 33 \\
\hline Oligochaeta & Tubificidae & Tubifex sp & 4 & 6 \\
\hline Gastropoda & Ampullariidae & Pomacea canaliculata & 0 & 1 \\
\hline Gastropoda & Viviparidae & Sinotaia reevei & 0 & 1 \\
\hline Gastropoda & Viviparidae & Sinotaia basicarinata & 0 & 2 \\
\hline \multicolumn{5}{|l|}{$\mathrm{x} 5$} \\
\hline Insecta & Chironomidae & Metriocnemus knabi coq & 1 & 0 \\
\hline Insecta & Chironomidae & Tendipes & 1 & 2 \\
\hline Oligochaeta & Tubificidae & Branchyura sowerbyi & 2 & 0 \\
\hline Oligochaeta & Tubificidae & Limnodrilus hoffmeisteri & 39 & 9 \\
\hline Oligochaeta & Tubificidae & Tubifex sp & 6 & 5 \\
\hline Polychaeta & Nereididae & Namalycastis longicirris & 1 & 0 \\
\hline Gastropoda & Viviparidae & Sinotaia basicarinata & 13 & 0 \\
\hline Gastropoda & Viviparidae & Sinotaia aeruginosa & 0 & 4 \\
\hline
\end{tabular}




\subsubsection{Clustering sampling sites basing on composition of zoobenthos}

The species of zoobenthos were divided into three clusters over two sampling periods (Figure 9). According to Figure $9 a$, zoobenthos composition at X1 and X4 were placed in the same cluster since the two locations were abundant with Limnodrilus hoffmeisteri belonging to Oligochaeta class that indicates high organic pollution. The sampling site X1 located at the place receiving frequently leachate and $X 4$ located at the place receiving infrequently discharge from the landfill to the paddy field and to the canal.
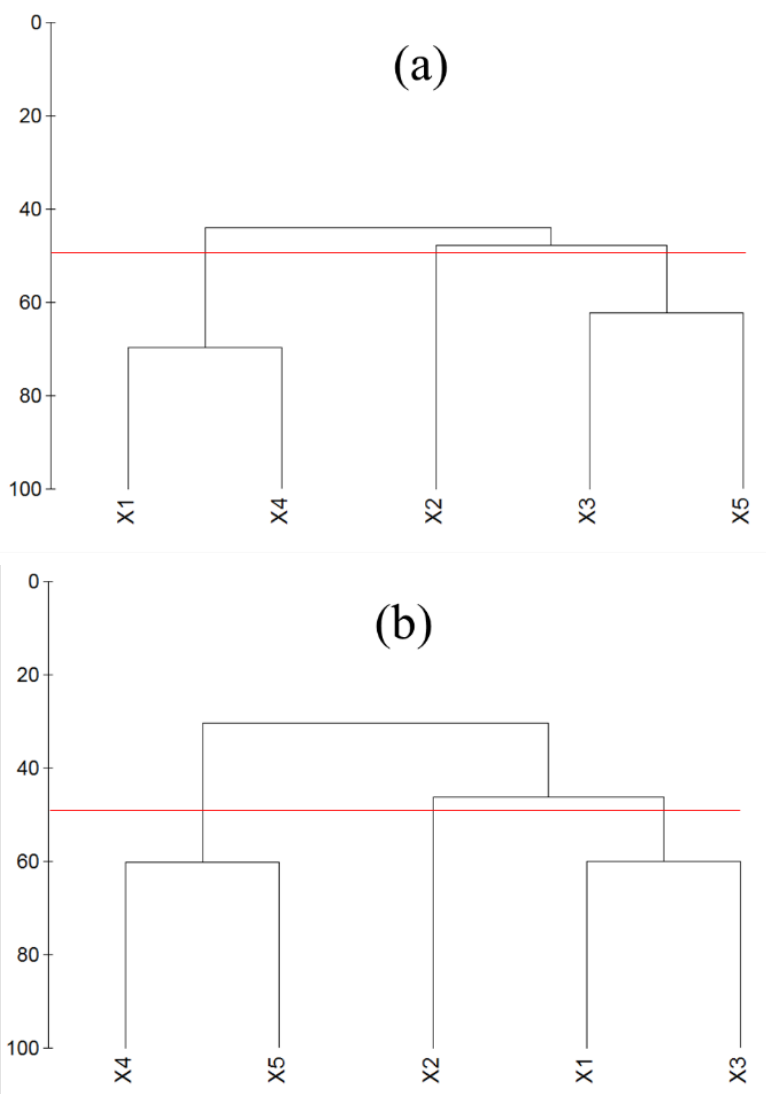

So the $X 4$ was influenced by both landfill leaching and farming practices. $X 2$ formed a distinct group since this site was the most dominant with of Limnodrilus hoffmeisteri species (56 individuals). It could be said that this site was the most organically polluted. The sites $X 3$ and $X 5$ were grouped in one cluster because these sites have the higher similarity in species composition and relative more abundance than the other sites. However, X3 and X5 were still predominated by Oligochaeta class.

Figure 9b shows the three clusters of zoobenthos in second sampling period. It can be seen that X2 still formed a separate cluster. $X 1$ and $X 5$ exchange their position in the dendrogram resulting in $X 4$ and $X 5$ forming a cluster while $X 1$ and $X 3$ forming another cluster. The use of cluster analysis is good for classification of sampling sites according to species composition and species abundance of zoobenthos.

\subsubsection{Assessment of water quality using zoobenthos}

The Shannon-Wiener diversity index $\left(\mathrm{H}^{\prime}\right)$ is widely used to indicate the status of water quality (Dung et al., 2007). The values of $\mathrm{H}^{\prime}$ at all the surveyed sites ranged from 0 to 1.34 indicating water quality from moderate pollution to heavy pollution (Table 3). The variation of H' does not depend on the number of zoobenthos but it depends on the frequency of occurrence of each species. For example, in the first round of sampling, there were occurrences of four species at X2 which was higher than that of X4 (only three species), but the $H^{\prime}$ at $X 4$ was higher than that at $X 2$. Approximate $60 \%$ and $40 \%$ of the surveyed sites had $H^{\prime}<1$ during the first and second sampling campaigns demonstrating that the aquatic environment at the study areas was moderately to heavily polluted with organic matters. The WQI index also indicated that the water environment in the study area was not suitable for agricultural irrigation.

Figure 9. Cluster analysis following sampling locations for zoobenthos during sampling period 1 (a) and period 2 (b)

Table 3. Using $\mathrm{H}^{\prime}$, ASPT and RBPIII as indication for water pollution level

\begin{tabular}{|c|c|c|c|c|c|c|}
\hline Sampling period & Sampling site & $\mathrm{X} 1$ & $x 2$ & X3 & $X 4$ & $\times 5$ \\
\hline \multirow[t]{3}{*}{ Period 1} & Number of species & 1 & 4 & 10 & 3 & 7 \\
\hline & $H^{\prime}$ & 0 & 0.55 & 1.34 & 0.73 & 1.15 \\
\hline & Water quality & $\begin{array}{l}\text { heavily } \\
\text { polluted }\end{array}$ & $\begin{array}{l}\text { heavily } \\
\text { polluted }\end{array}$ & $\begin{array}{l}\text { moderately } \\
\text { polluted }\end{array}$ & $\begin{array}{l}\text { heavily } \\
\text { polluted }\end{array}$ & $\begin{array}{l}\text { moderately } \\
\text { polluted }\end{array}$ \\
\hline \multirow[t]{3}{*}{ Period 2} & Number of species & 2 & 1 & 3 & 6 & 4 \\
\hline & $H^{\prime}$ & 0.45 & 0 & 1.04 & 1.05 & 1.26 \\
\hline & Water quality & $\begin{array}{l}\text { heavily } \\
\text { polluted }\end{array}$ & $\begin{array}{l}\text { heavily } \\
\text { polluted }\end{array}$ & $\begin{array}{l}\text { moderately } \\
\text { polluted }\end{array}$ & $\begin{array}{l}\text { moderately } \\
\text { polluted }\end{array}$ & $\begin{array}{l}\text { moderately } \\
\text { polluted }\end{array}$ \\
\hline \multirow[t]{4}{*}{ Period 1} & ASPT & 1 & 2.67 & 2.75 & 1.5 & 2.75 \\
\hline & Pollution level & heavily polluted & heavily polluted & heavily polluted & heavily polluted & heavily polluted \\
\hline & ASPT & 1.5 & 2 & 2.3 & 2.3 & 2.3 \\
\hline & Pollution level & heavily polluted & heavily polluted & heavily polluted & heavily polluted & heavily polluted \\
\hline
\end{tabular}




\begin{tabular}{|c|c|c|c|c|c|c|}
\hline Sampling period & Sampling site & $\mathrm{X} 1$ & $\mathrm{X} 2$ & X3 & $\mathrm{x} 4$ & $\times 5$ \\
\hline \multirow[t]{3}{*}{ Period 1} & RBP III & 10 & 9.4 & 9.3 & 10 & 9.1 \\
\hline & Organic pollution level & heavily polluted & heavily polluted & heavily polluted & heavily polluted & heavily polluted \\
\hline & Water quality & heavily polluted & heavily polluted & heavily polluted & heavily polluted & heavily polluted \\
\hline \multirow[t]{3}{*}{ Period 2} & RBP III & 10 & 10 & 9 & 9.7 & 9.2 \\
\hline & Organic pollution level & heavily polluted & heavily polluted & heavily polluted & heavily polluted & heavily polluted \\
\hline & Water quality & heavily polluted & heavily polluted & heavily polluted & heavily polluted & heavily polluted \\
\hline
\end{tabular}

Thuan et al. (2008) and Nhu et al. (2012) also used the ASPT to assess water quality in some canals in the Mekong Delta. The results show that, over the two sampling periods, the ASPT ranged from 1.00 to 2.75 (Table 3) indicating that the water was very contaminated. Similarly, the RBP III scores at the surveyed sites ranged from 9.1 to 10 signalizing that the aquatic environment was heavily polluted. Thus, the use of ASPT and RBP III for water quality assessment at the sites around the landfill resulted in the similar conclusion, that the water environment was highly polluted with organic matter.

It is important to note that, using the families of zoobenthos for grading the water quality may not be accurate since various species in the same family may have different capability of pollution tolerance. Members of Chironomidae family, for example, are found in most freshwater bodies, including those that are highly resistant to environmental pollutants, but also those that are sensitive to pollution (Dung et al., 2007). Using WQI to assess the water quality at the canals surrounding the landfill resulted in lesser pollution level than the use of $\mathrm{H}^{\prime}$, ASPT and RBP III. This could be understandable since the zoobenthos spends its life in the sediment where it can accumulate several types of pollutants. Therefore, the use of zoobenthos could be better represented for water quality and sediment status.

\section{Conclusions}

The water quality index, WQI, was in the range of 63-72 for the dry season and 53-67 for the rainy season showing that the surface water has been contaminated and does not meet the requirements of agricultural irrigation. The less diversity of zoobenthos, and the predominance of Limnodrilus hoffmeisteri (sampling period 1) and Tendipes (sampling period 2) at all sampling sites indicating surface water around the landfill is organically polluted. The biological indices including H', RBP III, ASPT showed organic pollution level of the surface water in the survey area was from moderate to heavy pollution. The causes of surface water pollution originate possibly mainly from the influence of landfill leachate and partly from agricultural activity. Environmental monitoring stations around the landfill should be established using both physical-chemical parameters and zoobenthos. Landfill leachate should be properly treated and friendly agricultural practices should be deployed to mitigate water pollution.

\section{References}

[1] American Public Health Association, 1998. Standard methods for the examination of water and wastewater, 20th edition, Washington DC, USA.

[2] Clarke, K.R. and Warwick, R.M. (1994). Changes in Marine Communities: An Approach to Statistical Analyses and Interpretation. Natural Environment Research Council, Plymouth.

[3] Dung, D.T., Tam, D.T., and Be, N.V., 2007. Aquatic characteristics in the biodiversity area in the Agro-forestry Area 184, Ca Mau. Can Tho University Journal of Science 7: 85-94 (in Vietnamese).

[4] Dung, D.T., Thuan, N.C., and Thien, N.T.C., 2008. Study on water body zoning based on zoobenthos populations. Can Tho University Journal of Science 1: 61-66 (in Vietnamese).

[5] Hellawell, J.M., 1986. Biological indicators of Freshwater Pollution and Environmental management. Elsevier, London, UK.

[6] Khoa, L.V., Quynh, N.X., Viet, V.Q., 2007. Environmental biological indicator, Education Publishing House, 2007.

[7] Lien, N.T.K., Giang, H.T., Ut, V.N., 2014. Composition of zoobenthos in Hau River. Can Tho University Journal of Science 2: 239-247 (in Vietnamese).

[8] Ministry of Natural Resources and Environment, 2015. Vietnam state of environment report for the period 2011 - 2015.

[9] Ministry of Natural Resources and Environment, 2015. QCVN 08-MT: 2015/BTNMT National technical regulation on surface water quality.

[10] National Environmental Protection Agency, 2011. Decision No. 879 /QĐ-TCMT-Guideline for calculating water quality index.

[11] Nhan, N.P., Toan, P.V., Nga, B.T., 2016. The characteristics of zoobenthos in some water bodies affected by agricultural cultivation in Hau Giang province. Can Tho University Journal of Science 42: 65-74 (in Vietnamese).

[12] Nhu, D.T.A., Nga, B.T., Dung, D.T., 2007. Hydrological, chemical and benthic characteristics at the section of Cai Dam canal, Phu Huu A INDUSTRIAL cluster, Chau Thanh district, Hau Giang province. Can Tho University Journal of Science 24: 17-18 (in Vietnamese). 
[13] Plafkin, J.L., Barbour, M.T., Porter, K.D., Gross, S.K., and Hughes, R.M., 1989. Rapid Bioassessment Protocols for Use in Streams and Rivers: Zoobenthos and Fish. EPA/444/4-89-001. U.S. Environ. Prot. Agency, Washington, D.C.

[14] Quynh, N.X., Pinder, C., Tilling, S., 2001. Identification of Vietnam freshwater invertebrates, Hanoi National University Publishing House, 2001 (in Vietnamese).

[15] Richard, S.T., Thorne, J., and Williams, W.P., 1997. The response of zoobenthos to pollution in developing countries: a multimetric system of bioassessment. Freshwater Biology 37: 671-686.

[16] Salah, E. A. M., Turki, A. M. \&amp; Othman, E. M. A., 2012. Assessment of water quality of Euphrates river using cluster analysis. Journal of Environmental Protection 3: 1629-1633.

[17] Thanh, D.N., Bai, T.T., Mien, P.V., 1980. Identification of North Vietnam freshwater invertebrates. Hanoi Science and Technology Publishing House, 1980 (in Vietnamese).

[18] Thuan, N.C., Chiem, N.H., and Dung, D.T., 2010. Assessing water quality by BMWPVIETNAM biological monitoring index in Cai May canal, Phu Tan district, An Giang province. Can Tho University Journal of Science 15: 125-131 (In Vietnamese.

[19] Wilhm, J. \& Dorris, T., 1968. Biological parameters for water quality criteria. Biological Science 18(6): $477-$ 481.

[20] Wijeyaratne, W.M.D.N and Kalaotuwave, K.M.B.P.P., 2017. Evaluation of the water and sediment quality of a lotic water-body in the western coastal region of Sri Lanka using Rapid Bioassessment Protocol II (RBP II) of benthic macroinverterbrates. Sri Lanka J. Aquat. Sci. 22(2): 85-97. 